\title{
Feed forensic strategy: Incorporating multivariate data analysis with high-performance liquid chromatography refractive index detector and differential scanning calorimeter for authentication of fish feed sources
}

Mohamed Haniff Hanafy Idris

Muhamad Shirwan Abdullah Sani ( $\sim$ shirwansany@iium.edu.my )

Amalia Mohd Hashim

Nor Nadiha Mohd Zaki

Yanty Noorzianna Abdul Manaf

Mohd Nasir Mohd Desa

Syariena Arshad

Mohd Hafis Yuswan

Mohd Sukri Hassan

Yus Aniza Yusof

Mohd Salleh Kamaruddin

Shuhaimi Mustafa

Method Article

Keywords: Triacylglycerol, Thermal properties, HPLC-RID, DSC, Principal component analysis, Discriminant analysis, Partial least square regression

Posted Date: December 13th, 2021

DOI: https://doi.org/10.21203/rs.3.rs-1156557/v1

License: (9) This work is licensed under a Creative Commons Attribution 4.0 International License.

Read Full License 


\section{Abstract}

This study authenticated fish feed sources and determined lard adulteration using dataset preprocessing, principal component analysis (PCA), discriminant analysis (DA) and partial least square regression (PLSR) on 19 triacylglycerols (TAGs) and 16 thermal properties (TPS). At cumulative variability $(90.625 \%)$ and Keiser-Meyer Olkin (KMO) value (0.811), the PCA identified strong factor loading variables, i.e., OLL, PLL, OOL, POL, PPL, POO, PPO, PSO, ICT and FHT in PC1 and LLLn, 000 and CT2 in PC2. These variables were significantly $(p<0.05)$ contributing to lard-palm-oil $(L-P O)$ clusters: $(1)$ POO, PPO and PPL (high loading) and OLL, PLL, OOL, ICT, POL, PSO and FHT (low loading) in 0:100 and 25:75 L-PO clusters; (2) CT2, 000 and LLLn (high loading) in 50:50 L-PO cluster; and (3) OLL, PLL, OOL, ICT, POL, PSO and FHT (high loading) and POO, PPO and PPL (low loading) in 72:25 and 100:0 L-PO clusters. Training, validation and testing datasets had $100 \%, 84.44 \%$ and $100 \%$ correct-classification, respectively at $p<$ 0.0001 of Wilks' lambda and $p<0.0001$ Fisher distance. The DA selected PLL, OOL, POL, PPL, PSO, ICT and FHT as the significantly authenticating biomarkers $(p<0.05)$. With determination coefficient $\left(R^{2}\right)$ (0.9693), mean square error (MSE) (38.382) and root mean square error (RMSE) (6.195), the PLSR's variable importance in the projection (VIP) identified the most influential biomarkers, i.e., PPL, POL, PPO, OOL, ICT, PLL, FHT, POO and OLL. The Z-test result $(p>0.05)$ indicated that the PLSR could determine the lard adulteration percentage in fish feed.

\subsection{Introduction}

The fish feed is formulated to effectively supply nutritional requirements and subsequently maintain physiological functions such as effective growth, reproduction and immune systems. For this purpose, a wide range of additives in the formulation of fish feed has been introduced. Besides antioxidants, enzymes and feed preservatives, the application of phytogenic feed additives (PFA) from roots, leaves and fruits in solid and liquid forms has received interest within the aquaculture industry (Encarnação, 2015). Among the PFAs, essential oils such as palm and seed oils are often used in the fish formulation due to nutritional quality, cheap source, generally recognized as safe and able to improve the feed digestibility and intake (Tyapkova et al., 2016). On account of these properties, there is an increasing interest to substitute the essential oil from PFA with lard. Although the addition of lard into fish feed has rendered a greater fish growth than other essential oils (Glencross, 2015), this substitution has raised concern among consumers, especially the vegetarians (Mutalib et al., 2015), Jews (Mukherjee, 2014) and Muslim consumers (Department of Standards Malaysia, 2019) when the fish feed manufacturers issue a false claim and taint the feed integrity. Muflih et al. (2017) reported that such activity became a national issue in Malaysia, where fish farmers fed their catfish with pig derivatives in several ponds at Batu Gajah, Tronoh and Papan, Perak. Hence, authentication of the fish feed source via analytical method is in dire need to address this issue.

Various testing methods have been utilized to address the issue of lard adulteration in products. Most testing use polymerase-chain-reaction (PCR) method, competitive indirect enzyme-linked immunosorbent assay (ELISA) and liquid chromatography methods, e.g. liquid chromatography time of flight mass 
spectrometer (LC-QTOF/MS) and liquid chromatography-mass spectrometer (LC/MS) to identify the presence of pork-originated adulterants. However, these methods are protein-targeted, complex, and prone to contamination (Yap \& Gam, 2019). Additionally, these methods are costly for maintenance in testing laboratories (Abbas et al., 2018). Due to these disadvantages, affordable analytical methods using highperformance liquid chromatography refractive index detector (HPLC-RI) and differential scanning calorimeter (DSC) (Naquiah et al., 2017) have successfully identified lard adulteration by analysing the triacylglycerols (TAGs) and thermal properties (TPs) of the samples (Azir et al., 2017; Noorzyanna et al., 2017; Yanty et al., 2017). Nonetheless, these identification methods were inadequate for authentication purposes since the lard adulteration was identified using sample profiling only. Moreover, these methods were applied to food products and have never been tested in fish feed. Hence, our study developed the authentication method for that purpose.

The comparison of sample profiles was insufficient for the authentication of fish feed sources. Although the HPLC-RI may render lower TAG detection sensitivity, it could not differentiate the fish feed source via comparison of the individual TAG in the sample with the TAG standard since the TAG of plant and animal origins possess almost similar characteristics distribution of TAG. Likewise, the TP of plant and animal oils have a similar profile pattern. These claims were evident from comparing TAG and TP profiles between palm oil and lard (Noorzyanna et al., 2017), although a thorough comparison was made via ANOVA. Naquiah et al. (2017) extended the ANOVA of the TP to multivariate data analysis (MDA) using principal component analysis (PCA); however, the research did not identify the potential biomarkers to discriminate the lard, authenticate the sample source and determine the composition of the lard adulteration in the sample.

The MDA, including PCA, discriminant analysis (DA) and partial least square regression (PLSR), requires pre-requisite analyses. These analyses entail outlier treatment (Bower, 2013a), dataset transformation for normal distribution (Granato, de Araújo Calado, et al., 2014) and test of dataset adequacy (Williams \& Brown, 2012), which were absent in previous PCA of feed. Without the fulfilment of these pre-requisite analyses, the MDA may lead to erroneous results and interpretation. Previous researches have neglected the qualitative authentication of fish feed analysis via DA and determination of lard adulteration level via PLSR. The MDA should test the training, validation and testing datasets of the fish feed before confirming the authentication ability of the analytical method and MDA models. Hence, this study outlined a guideline to explore the fish feed dataset, identify the significant biomarkers, and determine the level of lard adulteration in the fish feed. Subsequently, this study anticipated an adaptation of this guideline by the certification or regulatory bodies in developing fish feed guidelines or standards for research and testing laboratories.

\subsection{Methodology}

\subsection{Formulation of fish feed}


The ingredient percentages in the fish feed were calculated using WinFeed 2.8 software (Cambridge, UK). The fish feed was isonitrogenous at $30 \%$ crude protein as feed basis, which contained $6 \%$ of total oil, $0.5 \%$ of vitamin, $0.5 \%$ of mineral and $1 \%$ of yeast. The oil in the fish feeds was prepared at $0: 100,25: 75$, $50: 50,75: 25$ and $100: 0$ of L-PO ratio.

\subsection{Preparation of fish feed}

The ingredients of each diet formulation were weighed as determined by Winfeed 2.8 Software and mixed with $60 \mathrm{~mL}$ of pre-heated distilled water at $70^{\circ} \mathrm{C}$ using a food mixer (Giselle, Malaysia) for $3 \mathrm{~min}$. The mixture was transferred into a dough-making machine (Hengfeng, China) and mixed at $75 \mathrm{rpm}$ for $5 \mathrm{~min}$. The dough was kept at $25^{\circ} \mathrm{C}$ for $2 \mathrm{~h}$ to initiate the fermentation process, extruded at $7 \mathrm{~mm}$ diameter using a manual meat mincer and cut uniformly to produce consistent pellet length. The pellets were steamed (Little Homes, Malaysia) for $5 \mathrm{~min}$ and dried at $60^{\circ} \mathrm{C}$ for $3 \mathrm{~h}$ in a pre-heated electric oven (Memmert $\mathrm{GmbH}$, Germany). The dried pellets were then kept in a desiccator for $15 \mathrm{~min}$ and stored in a dry and closed container.

\subsection{Extraction of fish feed}

Before extraction, the dried pellets were ground for $5 \mathrm{~min}$ in a $240 \mathrm{~W}$ electrical blender (Panasonic MX337, Malaysia). The oil from $2 \mathrm{~g}$ dried fish feed was extracted with $150 \mathrm{~mL}$ petroleum ether at $60^{\circ} \mathrm{C}$ for $8 \mathrm{~h}$ in the Soxhlet apparatus (Khallouki et al., 2018). The extract was transferred into a pre-weighed flat bottom flask, concentrated using a rotary vacuum evaporator (Eyela $\mathrm{N}-1001$, Japan) at $40^{\circ} \mathrm{C}$ and frozen at $-20^{\circ} \mathrm{C}$ in a glass container.

\subsection{Triacylglycerol analysis of fish feed}

The frozen extract was thawed at $25^{\circ} \mathrm{C}$ for $1 \mathrm{~h}$ and warmed in a water bath at $60^{\circ} \mathrm{C}$ until completely melted. A concentration of $5 \%$ extract in chloroform $(\mathrm{w} / \mathrm{w})$ was subjected to TAG separation by highperformance liquid chromatography (HPLC) of 510 model (Waters, USA) and TAG detection by differential refractometer (RID) of 410 Waters model. A volume of $10 \mu \mathrm{L}$ of the extract was injected into the HPLC-RID and eluted by a pre-filtered eluent mixture of acetone: acetonitrile (63.5:36.5) at $1.5 \mathrm{~mL} / \mathrm{min}$ flow rate. The TAG separation was separated by $12.5 \mathrm{~cm} \times 4 \mathrm{~mm}$ i.d. Lichrosphere RP-18 column (Merck, Germany) at $30^{\circ} \mathrm{C}$. The detected peak was confirmed with a mixture of 19 TAG standards (Waters, USA) containing dilinoleoyl-3-linolenileoyl glycerol (LLLn), trilinoleoyl glycerol (LLL), trimyristoyl glycerol (MMM), dilinoleoyl-1-oleoyl glycerol (OLL), dilinoleoyl-1-palmitoyl glycerol (PLL), myristoyl- palmitoyllinoleoyl glycerol (MPL), dioleoyl-3-linoleoyl glycerol (OOL), palmitoyl-oleoyl-linoleoyl glycerol (POL), dipalmitoyl-1-linoleoyl glycerol (PPL), trioleoyl glycerol (OO0), dioleoyl-1-palmitoyl glycerol (POO), dipalmitoyl-3-oleoyl glycerol (PPO), tripalmitoyl glycerol (PPP), dioleoyl-1-stearoyl glycerol (SOO), palmitoyl-stearoyl-oleoyl glycerol (PSO), dipalmitoyl-3-stearoyl glycerol (PPS) and tristearoyl glycerol 
(SSS), 1,3-distearoyl-2-oleoyl (SOS) and 1-stearoyl-2-palmitoyl-3-oleoylrac-glycerol (SPO). The confirmed peaks were reported as peak area percentages. The TAG analysis was performed in triplicates (Yanty et al., 2017).

\subsection{Thermal analysis of fish feed samples}

Thermal analysis was carried out using a differential scanning calorimeter (DSC) of 823 model equipped with a station of thermal data analysis (Mettler Toledo, Switzerland). An approximate of 4-8 $\mathrm{mg}$ the extract was placed in an aluminium pan, hermetically sealed and analysed according to continual temperature setting: heated at $70^{\circ} \mathrm{C}$ for $1 \mathrm{~min}$, cooled at $5^{\circ} \mathrm{C} / \mathrm{min}$ to $-70^{\circ} \mathrm{C}$, held at $-70^{\circ} \mathrm{C}$ for $1 \mathrm{~min}$ and heated at $5^{\circ} \mathrm{C} / \mathrm{min}$ to $70^{\circ} \mathrm{C}$. The cooling procedure was executed with nitrogen (99.999\% purity) at $\sim 20$ $\mathrm{mL} / \mathrm{min}$. An empty, hermetically sealed aluminium pan was used as the reference. Thermal properties (TPs) of cooling and heating activities, including cooling and heating temperatures of the fish feed, were recorded. Thermograms of the fish feeds were compared to identify the numbers of cooling and heating temperatures.

\subsection{Dataset pre-processing}

The percentage of peak area of TAG and TP was imported to the dataset table in XLSTAT 2017 software (Addinsoft, Paris, France). An about 45 fish feeds entailing 19 TAGs, and 16 TPs was pre-processed to reduce the variation of the TAGs and TPs in the dataset. The dataset was analysed via box-and-whisker plot (BWP) to treat outlier, ANOVA test, dataset transformation, KMO test and PCA.

\subsubsection{Outlier treatment}

Prior to the ANOVA test and PCA, the individual TAG and TP were subjected to outlier treatment using the BWP method from a standardized dataset. The confidence interval of the BWP was set at $95 \%$. The skewness of the BWP was examined to confirm the need for dataset transformation. The dataset, which showed different patterns within the individual TAG and TP, was discriminated and shown in the BWP as an outlier. Outlier value exceeded three times the box's height was signed with a dot, star or asterisk (Saiful et al., 2019) and replaced with the variable's mean value.

\subsubsection{Analysis of variance}

Results were expressed as mean and standard deviation of triplicate analyses for the distribution of TAGs and TPs of the fish feed. The ANOVA test of Tukey's test was applied to determine the significant difference between means of the TAGs and TPs at a 95\% confidence level $(p<0.05)$.

\subsubsection{Dataset transformation}


To ensure dataset following normal distribution prior to the PCA, the dataset normality was tested using Shapiro-Wilk (SWT), Anderson-Darling (ADT), and Lilliefors (LT) tests at a of 0.05. The dataset was transformed using standardize $n-1$, standardize $(n)$, centre, standard deviation ${ }^{-1}(n-1)$, standard deviation ${ }^{-1}$ (n), rescale from 0 to 1, rescale from 0 to 100, and Pareto transformation methods. The undetected thermal properties were acknowledged as missing data and subjected to removal before the dataset transformation. The transformation of each TAG and TP was employed to ensure the transformed dataset remained closer to the original dataset (Ismail et al., 2021). The normal distribution of the transformed dataset was tested, and the best transformation method and normality test were selected from the result.

\subsection{Dataset exploratory by principal component analysis}

The PCA of Pearson correlation was employed to examine the dataset pattern, explore the TAGs and TPs contributions to the fish feeds, find and explain the TAGs and TPs correlation and reduce the dataset significantly $(p<0.05)$ into smaller sets of new independent variables, which were called as principal components (PCs) via the following formulae:

$$
S_{p q}=f_{p 1} v_{1 q}+f_{p 2} v_{2 q}+f_{p 3} v_{3 q}+\cdots+f_{p n} v_{n q}
$$

Where $S$ is the component score, $f$ is the FL, $v$ is the concentration of TAG and TP, $p$ is the PC number, $q$ is the sample number, and $n$ is the total number of TAG and TP.

In this study, two PCAs were executed. The first PCA was executed, and cumulative variability (CV), eigenvalue (EV) and KMO and FL values were evaluated at a significant level (a) of 0.05 .

Using TAGs and TPs with strong FL, the second PCA was executed to produce a new TAG and TP plot and a biplot of TAG, TP, and fish feed. The cumulative variability, eigenvalue and KMO and FL value were evaluated and compared to the first PCA. The FL and correlation of TAGs and TPs were assessed, and the apportionment of TAGs and TPs to the fish feed clusters was examined. From the second PCA, the significant TAGs and TPs contributed to the fish feed clusters were proposed as the biomarkers (Idris et al., 2021).

\subsection{Authentication of fish feed source by discriminant analysis}

In this study, DA was employed to authenticate fish feed. The same fish feed dataset was acknowledged as training and validation datasets while testing dataset consisting of 25 known fish feeds were prepared for authentication purposes. 
A new column labelled as 'cluster' was added to the dataset, and the fish feeds were assigned as 'palm oil' for 0:100 L-PO, 'lard + palm oil' for 25:75 L-PO, 50-50 LPO and 75:25 L-PO and 'lard' for 100:0 LPO clusters. The DA model was executed at set a of 0.05 . The function of the DA model is as follows:

$$
f\left(C_{a}\right)=k_{a}+\sum_{a=1}^{n} w_{a} T_{a}
$$

Where a was the number of fish feed cluster $(C), k$ was the constant for each cluster, $n$ is the number of TAG, and TP $(T)$ used to classify the training dataset into the cluster, and $w$ is the weight coefficient which was assigned by the DA to the selected $T$. The DA model was developed for fish feed, the dissimilarity of palm oil, L-PO and lard clusters was explored, and 25 known fish feeds were authenticated. The significant TAGs and TPs that caused the dissimilarity between the clusters were identified (Sharin et al., 2021).

\subsection{Determination of lard adulteration percentage by partial least square regression}

The PLSR is employed to develop the PLSR model and determine the L-PO composition in fish feed. The training, validation and training datasets were utilized in this study. A new column labelled as 'lard adulteration percentage' was to the dataset, and the fish feeds were assigned as ' $0 \%$ ', ' $25 \%$, ' $50 \%$ ', '75\%' and ' $100 \%$ ' lards according to the percentage of adulterated lard in the fish feeds. The PLSR model was executed at set $a$ of 0.05 . The function of the DA model is as follows:

$Y=X \times V$

where a mathematical relation was created between the matrix of the fish feed training dataset $(X)$ and the regression coefficient vector $(V$. A principal component of PLSR was also developed in this stage. Then, the validation dataset was employed to optimize this mathematical relation to set up calibration. Then the lard adulteration percentage $(Y)$ of the 25 known fish feeds were determined based on this calibration (Alexandre et al., 2010).

The PLSR model was developed, and the model characteristics such as determination coefficient $\left(R^{2}\right)$, low mean square error (MSE) and root mean square error (RMSE) were evaluated. The list of VIPs was assessed to determine the significant TAGs and TPs (biomarkers) in the model. The Z-test value of the predicted and actual values was calculated. The determined value of the fish feed was examined and evaluated to confirm the ability of the PLSR model (Abdullah Sani et al., 2021).

\subsection{Result And Discussion}




\subsection{Outlier treatment}

Table 1 shows the detected outliers from the BWP of the fish feed. The fish feed with 0:100, 25:75, 50:50, 75:25, and 100:0 L-PO mixtures presents $1,3,10,2$, and 5 outliers, respectively whereby, the fish feed with 50:50 LPO mixture had the highest number of outliers. The outlier treatment by replacing the outlier with the mean of each parameter (Berg et al., 2006) decreased the PCA's dataset distortion. However, previous research had never performed the outlier treatment before the PCA, which analysed TAGs and thermal properties (Golijan et al., 2019). Post outlier treatment of the BWP, the new dataset was also subjected to dataset normalization prior to the PCA.

\subsection{Triacylglycerol of fish feed}

The TAG percentage in the fish feeds is presented in Table 1. The TAGs of fish feed containing 0:100 LPO, 25:75 L-PO, 50:50 L-PO, 75:25 L-PO and 100:0 L-PO mixtures from $0.00 \pm 0.00 \%$ (PPP, SSS and SOS) to $5.12 \pm 0.30 \%$ (POO), $0.00 \pm 0.00 \%$ (PPP) to $9.05 \pm 0.59 \%$ (POO), $0.00 \pm 0.00 \%$ (SPO, SSS and PPP) to $25.01 \pm 1.40 \%$ (POO), $0.03 \pm 0.04 \%$ (MPL) to $22.93 \pm 1.17 \%$ (POO), $0.00 \pm 0.00 \%$ (SPO) to $22.32 \pm 0.82 \%$ (POL), respectively. The POO had the highest percentage in all fish feed formulations, while POL had the highest percentage in fish feed with 100:0 L-PO. The high content of POO in fish feed containing 0:100 LPO was in line with Indelicato et al. (2017) finding except for the latter reported 1,3-dipalmitoyl-2-oleoyl glycerol (POP) presence. Likewise, the highest content of POL in fish feed containing 100:0 L-PO was comparable to the POL determined by Yanty, Marikkar, Man, \& Long (2011).

For the fish feed with $100 \%$ palm oil, the ranking of TAG percentage as follows: $\mathrm{PPP}<\mathrm{SOS}<\mathrm{SSS}<\mathrm{MMM}$ $<\mathrm{LLL}<\mathrm{MPL}<\mathrm{PSO}<\mathrm{SOO}<\mathrm{LLLn}<\mathrm{OLL}<\mathrm{SPO}<\mathrm{PPS}<\mathrm{OOL}<\mathrm{PLL}<000<\mathrm{PPL}<\mathrm{POL}<\mathrm{PPO}<\mathrm{POO}$. In contrast, the fish feed of $100 \%$ lard exhibited different ranking of TAG percentage as follows: SPO $<$ SSS $<\mathrm{MMM}<\mathrm{PPP}<\mathrm{MPL}<\mathrm{SOS}<\mathrm{LLL}<\mathrm{SOO}<\mathrm{PPL}<\mathrm{LLLn}<\mathrm{PPS}<000<\mathrm{OLL}<\mathrm{PSO}<\mathrm{OOL}<\mathrm{PLL}<\mathrm{PPO}<$ POO < POL. It was evident that the ranking of TAGs in 25:75 L-PO, 50:50 L-PO, 75:25 L-PO mixtures were different from each other. The different rankings indicated the addition of lard into fish feed containing palm oil affected the distribution of the TAGs.

All fish feeds exhibited a significant difference in OOL, POL, PPL, PPO percentages $(p<0.05)$. Of these TAGs, fish feed with 100:0 L-PO possessed the highest percentage OOL $(7.97 \pm 0.36 \%)$ and POL $(22.32 \pm$ $0.82 \%)$ while fish feed with 0:100 L-PO showed the highest percentage of PPL $(11.20 \pm 0.82 \%)$ and PPO (22.52 $\pm 1.54 \%$, and vice versa. The 25:75 L-PO, 50:50 L-PO and 75:25 L-PO mixtures had moderate percentage of OOL ( $4.31 \pm 0.59 \%$ to $6.73 \pm 0.50 \%)$, POL ( $15.77 \pm 0.41 \%$ to $20.03 \pm 0.64 \%)$, PPL (4.92 \pm $0.31 \%$ to $9.05 \pm 0.59 \%)$ and PPO $(12.37 \pm 0.86 \%$ to $18.77 \pm 1.61 \%)$ with significant differences $(p<0.05)$. From the ANOVA result, OOL, POL, PPL, PPO could become potential biomarkers to discriminate fish feed sources.

\subsection{Thermal properties of fish feed}

The thermal properties of the fish feeds are presented in Table 1. The thermal analysis of the fish feeds yielded one starting cooling temperature $\left(4.68 \pm 0.47^{\circ} \mathrm{C}\right.$ to $\left.13.53 \pm 0.65^{\circ} \mathrm{C}\right)$ and one ending cooling 
temperature $\left(-29.92 \pm 5.51^{\circ} \mathrm{C}\right.$ to $\left.-49.13 \pm 7.55^{\circ} \mathrm{C}\right)$. Yanty, Marikkar, \& Abdulkarim (2014) analysed palm oil and recorded cooling temperatures at $20.1^{\circ} \mathrm{C}$ and $3.05^{\circ} \mathrm{C}$ as compared to $0.45^{\circ} \mathrm{C},-3.43^{\circ} \mathrm{C}$, and $-19.28^{\circ} \mathrm{C}$ in our study due to the former analysed palm oil only while our study analysed the fish feed extract containing the palm oil. The fish feed containing 100:0 L-PO showed the cooling temperature at $10.24^{\circ} \mathrm{C}$, $4.87^{\circ} \mathrm{C}, 2.70^{\circ} \mathrm{C},-1.69^{\circ} \mathrm{C},-14.79^{\circ} \mathrm{C}$ and $-43.37^{\circ} \mathrm{C}$, which contradicted the observed cooling temperature at $17.99^{\circ} \mathrm{C}$ and $11.98^{\circ} \mathrm{C}$ by Azir et al., 2017 and $9^{\circ} \mathrm{C}$ and $-19^{\circ} \mathrm{C}$ by Naquiah, Marikkar, Mirghani, Nurrulhidayah, \& Yanty (2017). Among the fish feeds in Table 1, all fish feeds recorded six cooling temperatures while fish feed with 0:100 L-PO recorded three cooling temperatures. Although the absence of three cooling temperatures may distinguish the fish feed containing 0:100 L-PO from other fish feed, no significant difference of temperature $(p<0.05)$ was observed at cooling starting temperature, cooling temperature, and cooling ending temperature in all fish feeds.

The thermal analysis of the fish feeds (Table 1$)$ yielded one starting heating temperature $\left(-25.67 \pm 3.01^{\circ} \mathrm{C}\right.$ to $-33.46 \pm 1.25^{\circ} \mathrm{C}$ ) and one ending heating temperature $\left(15.26 \pm 0.14^{\circ} \mathrm{C}\right.$ to $\left.29.18 \pm 1.85^{\circ} \mathrm{C}\right)$. The fish feed with 0:100 L-PO and 100:0 L-PO exhibited four and five heating temperatures, respectively, compared to six heating temperatures in other fish feeds. These results were entirely contrary to those shown in the DSC analysis of palm oil by Yanty, Marikkar, \& Abdulkarim (2014b), which exhibited five heating temperatures at $14.00^{\circ} \mathrm{C}, 10.00^{\circ} \mathrm{C}, 8.00^{\circ} \mathrm{C}, 6.00^{\circ} \mathrm{C}$ and $-4.00^{\circ} \mathrm{C}$. These results also contradicted three recorded heating temperatures at $-4.00^{\circ} \mathrm{C}, 28.78^{\circ} \mathrm{C}$ and $34.09^{\circ} \mathrm{C}$ in lard (Azir et al., 2017). The absence of these heating temperatures may facilitate the identification of the fish feed containing 0:100 L-PO and 100:0 L-PO. Similar to the result of cooling activity, all fish feeds did not exhibit a significant difference in all heating temperatures. Therefore, the lack of an insignificant difference in the temperatures could not differentiate the fish feeds containing lard-palm-oil mixtures.

This ANOVA result considered only the significant difference of the TAGs and thermal properties and was subjected to further improvement by applying PCA for the multivariate dataset (Jasour et al., 2018). Although negligible research has adopted the application of PCA to explore the dataset entailing thermal properties, Green et al. (2020) recommended employing TAGs and PCA to investigate the source of edible oils. This approach is practical to uphold the fish feed integrity as claimed by manufacturers and bring confidence to consumers.

\subsection{Dataset transformation}

This study investigated issues of (1) which dataset transformation was suitable for TAGs and TPs analysis in fish feed and (2) which normality test was the best to examine the dataset normality.

The most common dataset transformation was the standardize (n-1) followed by other dataset transformations deemed suitable according to sample type. Supplementary data 1, 2 and 3 show the $p$ value of normality test for SWT, ADT and LT, respectively. After dataset transformations, not all TAGs and TPs of the transformed dataset demonstrated normal distribution. 
Before dataset transformation, the normality test of SWT exhibited 13 TAGs and 15 TPs that followed a normal distribution (Supplementary 1). Post transformation via standardize (n-1), OOL showed normal distribution with $0.0491 \mathrm{p}$-value. The SWT identified 14 TAGs and 15 TPs that followed normal distribution after the dataset transformations. The ADT exhibited 10 TAGs, and 14 TPs followed a normal distribution before the dataset transformation (Supplementary 2). The PPL and PPO had followed the normal distribution after standardize ( $n-1)$ transformation. Hence, the ADT resulted in 16 TAGs and 14 TPs that followed normal distribution after the dataset transformations. The LT showed 10 TAGs, and 14 TPs followed the normal distribution before the dataset transformation (Supplementary 3). After the dataset underwent all transformations, no TAGs and TPs followed a normal distribution. From these findings, the ADT was recommended as the best normality test to investigate dataset normality of TAGs and TPs in the fish feed, which was in agreement with the study of Razali, Wah, \& Sciences (2011), who found that normality test of ADT was effective in low sample size $(n<10000)$. Besides, Bower $(2013 b)$ recommended the acceptance of the non-normal distribution of the dataset because the instrumental or continuous measurement of the sample was principally following the normal distribution.

There have been several studies investigating the suitability of different dataset transformations for specific matrices. For instance, the standardize (n), 0 to 100 rescaling and Pareto transformations were corroborated suitable for sugarcane spirits (Granato, Cardoso, et al., 2014), water quality (Juahir et al., 2011) and plant volatiles (Gogna et al., 2015) matrices, respectively. For the fish feed matrix, Bloomfield, Elsdon, Walther, Gier, \& Gillanders (2011) did not transform the fish feed dataset, possibly due to the principle that the dataset distribution will never achieve normal distribution (Rodriguez, 2020). However, our study had proven that the standardize $(n-1)$ transformation was suitable for the fish feed matrix. This study proposed testing the fish feed dataset with various transformations to confirm the most suitable transformation. Hence, 10 TAGs and 14 TPs were not transformed, and LLL, PPL and PPO were transformed using standardize ( $\mathrm{n}-1)$. Although OLL, PLL, OOL, POL, OOO, POO, CT2 and HT4 remained with non-normal distribution after the transformations, these variables were also transformed using standardize (n-1) prior to PCA.

\subsection{Dataset exploratory by principal component analysis}

The exploratory of the dataset via the first PCA demonstrated PC1 and PC2 with eigenvalue (EV) $>1$ (Falcó et al., 2019), which explained $57.766 \%$ cumulative variability (CV) of the dataset (Table 2). The EV and percentage variability (PV) reflect the size and significant PC $(p<0.05)$, whereby PC1 has a larger EV than PC2. The EV information supported or our result that the EVs decreased as the PC number increased, i.e. $P C 1(E V=13.318, P V=38.050)>P C 2(E V=6.900, P V=19.715)$. Although there is no cut-off value of EV or PV, our study adopts the suggested EV $>1$ as a principal guideline for feed composition study (Falcó et al., 2019). The KMO test calculated the value of 0.513 for the first PCA. Although no fish feed study has determined the KMO value and provided the acceptance limit specifically for the fish feed matrix, KMO > 0.5 indicated compliance with PCA's dataset adequacy (Kaiser, 1974; Williams \& Brown, 2012). 
The first PCA generated TAGs and TPs with strong FL (FL $\geq|0.75|$ ): OLL, PLL, OOL, POL, PPL, POO, PPO, PSO, ICT and FHT in PC1 and LLLn, 000 and CT2 in PC2. The TAGs and TPs with moderate FL $(|0.500|<$ FL < |0.749|) were LLL, PPP, CT1, CT3, FCT, HT4 and HT6 in PC1 and SOO, SOS, CT3, CT5, IHT, HT1, HT3 and HT4 in PC2. The PCA also exhibited weak FL (FL $\leq|0.499|)$ of MPL, SPO, SSS, CT6, HT2, and HT5 in PC1 and PPS, MMM and CT4 in PC2.

By executing the second PCA using TAGs and TPs with strong FL from the first PCA, the second PCA demonstrated PC1 and PC2 with higher CV (90.625\%) and KMO (0.811) than of the first PCA (Table 2), while the TAGs and TPs with strong FL remained in the same criterion. This result confirmed that 10 TAGs and 3 TPs with strong FL were adequate to explain the $90.625 \%$ variation of the fish feed dataset. Our study also found the TAGs with strong FL were the ones with oleic acid and palmitic acid in their chemical structure. The ICT and CT2 were attributed to the amount of saturated and unsaturated TAGs, and FHT was associated with the melting of crystallized and polymorphic transitions of fat (Azir et al., 2017).

The positive and negative signs of the FL in the second PCA (Table 2) explained the correlation between the TAGs and TPs. The TAGs and TPs that shared the same FL sign were positively correlated, indicating that positive change of a TAG or TP would positively change other TAGs and TPs and vice versa. Based on this principle, two groups had their correlations in PC1: (1) PPL, PPO and PPO in group 1 were positively correlated, and (2) OLL, PLL, OOL, POL, PSO, ICT and FHT in group 2 were positively correlated, and (3) TAGs and TPs in group 1 and 2 were negatively correlated. Likewise, CT2 was negatively correlated with LLLn and 000 in PC2. The TAG and TP plots of Figure 1 (a) confirmed these correlations. This plot also rendered additional information regarding TAGs and TPs with weak or without correlations when the directions of their FL were $\sim 90^{\circ}$ (Hair et al., 2014), i.e. POO, PPO and PPL against CT2, 000 and LLLn.

Figure 1 (b) depicts the biplot of TAG and TP in fish feed. The biplot generated five clusters that corresponded to each L-PO mixture. The biplot showed the TAGs and TPs that significantly contributed ( $p$ $<0.05$ ) to each L-PO cluster: (1) high loading of POO, PPO and PPL and low loading of OLL, PLL, OOL, ICT, POL, PSO and FHT in 0:100 and 25:75 L-PO clusters, (2) high loading of CT2, 000 and LLLn in 50:50 L-PO cluster and (3) high loading of OLL, PLL, OOL, ICT, POL, PSO and FHT and low loading of POO, PPO and PPL in 72:25 and 100:0 L-PO clusters. The POO, PPO and PPL were of high loading in 0:100, and 25:75 L-PO clusters were due to high concentration of oleic acid and palmitoleic acids while high loading of OLL, PLL, OOL, ICT, POL, PSO in 72:25 and 100:0 L-PO clusters corresponded to a high concentration of oleic and linoleic acids (Indrasti et al., 2010). The high loading of ICT and FHT in 72:25 and 100:0 L-PO clusters was attributed to the polymorphic transition of high concentration of saturated and unsaturated TAGs (Azir et al., 2017). The PCA had selected the OLL, PLL, OOL, POL, PPL, POO, PPO, PSO, ICT, FHT, LLLn, 000 and CT2 as the biomarkers to identify the fish feed source. Nonetheless, the PCA is an unsupervised MDA which is more suitable for dataset exploratory; hence this study employed these biomarkers to authenticate fish feed source via DA and determine the percentage of lard adulteration via PLSR. 


\subsection{Authentication of fish feed source by discriminant analysis}

The DA was performed on the training and validation datasets to (1) develop a DA model for fish feed, (2) explore the dissimilarity of palm oil, L-PO and lard clusters, (3) authenticate 25 known fish feed in the testing dataset and (4) identify the significant TAGs and TPs that caused the dissimilarity between the clusters. Table 3 shows the classification matrix of training, validation, and testing datasets by the DA model. The $p$-value of Wilks' lambda for the DA model $(p<0.0001)$ indicated that the three clusters were significantly different from each other. This result was confirmed by the calculated $p$-value of Fisher distance $(p<0.0001)$ between the two clusters. The training and validation datasets had $100 \%$ and $84.44 \%$ correct classification values, respectively. Although the correct classification of the latter was lower than the former, $100 \%$ correct classification was recorded for the testing dataset, thus proved the DA model was reliable to authenticate 25 known fish feeds (Figure 2). The DA model had selected PLL, OOL, POL, PPL, PSO, ICT and FHT as the significant biomarkers $(p<0.05)$ from the 10 TAGs and 3 TPs proposed by the PCA.

\subsection{Determination of lard adulteration percentage by partial least square regression}

The PLSR result in Table 4 shows the determination for the testing dataset consisting of the known percentage of lard adulteration in the fish feeds. The PLSR had developed a model equation as follows:

Lard adulteration, $\%=18.082+1.165 \mathrm{ICT}+1.047 \mathrm{CT} 2+0.648 \mathrm{FHT}+0.951 \mathrm{LLLn}+3.313 \mathrm{OLL}+3.731 \mathrm{PLL}+$ 3.8750OL + 3.949POL - 3.967PPL + 0.199000 - 3.626POO - 3.913PPO + 0.997PSO.

This model had a strong $\mathrm{R}^{2}$ of 0.9693 and low MSE and RMSE of 38.382 and 6.195, respectively. Also, analysis of VIP had rendered the ranking of TAGs and TPs according to their influence on the model. The developed ranking was as follows: PPL (1.211) > POL (1.206) > PPO (1.195) > OOL (1.183) > ICT (1.168) $>$ PLL (1.139) > FHT (1.118) > POO (1.107) > OLL (1.012) > PSO (0.911) > LLLn (0.393) > CT2 (0.320) > 000 (0.061). According to Mercader, Duchowicz, \& Sivakumar (2016), a variable with VIP $>1$ has a strong positive impact on the PLSR model; thus, all TAGs and TPs except PSO, LLLn, CT2 and 000 became the most significant biomarkers in this model. Additionally, PSO was the TAGs with the lowest FL determined in the PCA, while LLLn, 000 and CT2 were the TAGs and TP of the PC2 in the PCA. Hence, the PLSR model only selected the TAGs and TPs with strong FL in the PC1 of the PCA as the most significant biomarkers. On the contrary, the PSO was included in the list of significant biomarkers by DA model to authenticate the fish feed source qualitatively.

Table 4 also exhibited the determination of lard adulteration percentage for five clusters of fish feed. Based on the mean and standard deviation, the determined value for each cluster was within the actual value. The determined value also fell between the $95 \%$ lower and upper bounds of the determined value. Nonetheless, the relative error of the determined value decreased as the lard adulteration percentage 
increased, signifying the PSLR model was more sensitive at a higher percentage of lard adulteration. Since the Z-test value showed $p$-value $>0.05$, the null hypothesis $(\mathrm{Ho})$ was accepted indicated the percentage means of the determined and actual lard adulteration were not significantly different. This result proved that the PLSR model could determine the percentage of lard adulteration in the fish feed.

\subsection{Conclusion}

The demand to produce fish feed for aquaculture fields has shown exponential growth, which requires the testing laboratory's authentication as a feed forensic tool. The TAG and TP testing analyses by HPLC-RID and DSC incorporated with PCA, DA and PLSR are imperative to address the false claim and ensure feed integrity from the manufactures. The analysis undergoes procedures of fish feed extraction, TAG and TP analyses, dataset pre-processing, exploration of the dataset via PCA, authentication of the fish feed by DA and determination of lard adulteration percentage in fish feed by PLSR a guideline to avoid false-positive and negative results. However, it is recommended that the TAG and TP analyses undergo method validation and verification (MVV) to determine the limit of detection (LOD) and quantification (LOQ) of the method before the dataset analysis. Also, this manuscript explained the PCA, DA and PLSR, which were the frequently utilized MDA for authentication, while other MDA such as multiple linear regression (MLR) and principal components regression (PCR) were not discussed. Since limited research focuses on fish feed testing, this manuscript may guide the researchers and testing laboratories to extend their scope of analysis and suggest applying HPLC-RID, DSC and MDA as an option for the fish feed testing. The certification or regulatory bodies at the governmental level and testing laboratories could adapt this guideline to develop a standard of TAG and TP analyses for authentication of fish feed sources.

\section{Declarations}

\subsection{Acknowledgement}

The authors would like to acknowledge the Ministry of Higher Education Malaysia for granting Konsortium Institut Halal IPT Malaysia (KIHIM) a research grant no. 63900911-10205.

\subsection{Conflict of interest statement}

We declare no conflict of interest.

7.0 Research involving human participants and/or animals

We declare no human and/or animals involved in this study.

\subsection{Informed consent}

All authors have granted permission in full knowledge for the publication of this study.

\section{References}


1. Abbas, O., Zadravec, M., Baeten, V., Mikuš, T., Lešić, T., Vulić, A., Prpić, J., Jemeršić, L., \& Pleadin, J. (2018). Analytical methods used for the authentication of food of animal origin. Food Chemistry, 246, 6-17. https://doi.org/10.1016/j.foodchem.2017.11.007

2. Abdullah Sani, M. S., Ismail, A. M., Azid, A., \& Samsudin, M. S. (2021). Establishing forensic food models for authentication and quantification of porcine adulterant in gelatine and marshmallow. Food Control, 130(June), 108350. https://doi.org/10.1016/j.foodcont.2021.108350

3. Alexandre, T. L., Goraieb, K., Bueno, M. I. M. S., \& Wiley, J. (2010). Quality control of beverages using XRS allied to chemometrics: Determination of fixed acidity, alcohol and sucrose contents in Brazilian cachaca and cashew juice. X-Ray Spectrometry, 285-290. https://doi.org/10.1002/xrs.1262

4. Azir, M., Abbasiliasi, S., Azmi, T., Ibrahim, T., Noorzianna, Y., Manaf, A., Sazili, A. Q., \& Mustafa, S. (2017). Detection of lard in cocoa butter - Its fatty acid thermal characteristics. Foods, 6(98), 1-12. https://doi.org/10.3390/foods6110098

5. Berg, R. A. Van Den, Hoefsloot, H. C. J., Westerhuis, J. A., Smilde, A. K., \& Werf, M. J. Van Der. (2006). Centering, scaling, and transformations: Improving the biological information content of metabolomics data. BMC Genomics, 7(142), 1-15. https://doi.org/10.1186/1471-2164-7-142

6. Bloomfield, A. L., Elsdon, T. S., Walther, B. D., Gier, E. J., \& Gillanders, B. M. (2011). Temperature and diet affect carbon and nitrogen isotopes of fish muscle: Can amino acid nitrogen isotopes explain effects? Journal of Experimental Marine Biology and Ecology, 399(1), 48-59.

https://doi.org/10.1016/j.jembe.2011.01.015

7. Bower, J. A. (2013a). Descriptive statistics. In J. A. Bower (Ed.), Statistical Methods for Food Science: Introductory Procedures for the Food Practitioner (Second Edi, pp. 44-90). John Wiley \& Sons, Ltd. https://doi.org/10.1007/978-3-642-25697-4_4

8. Bower, J. A. (2013b). The nature of data and their collection. In J. A. Bower (Ed.), Statistical Methods for Food Science: Introductory Procedures for the Food Practitioner (Second Edi, pp. 15-43). John Wiley \& Sons, Ltd. Published. https://doi.org/10.1002/9781118541593.ch2

9. Department of Standards Malaysia. (2019). Malaysian Standard MS 1500: 2019 Halal food - General requirements (Third revision).

10. Encarnação, P. (2015). Functional feed additives in aquaculture feeds. In Aquafeed Formulation (pp. 217-237). https://doi.org/10.1016/B978-0-12-800873-7.00005-1

11. Falcó, I., Randazzo, W., Sánchez, G., López-Rubio, A., \& Fabra, M. J. (2019). On the use of carrageenan matrices for the development of antiviral edible coatings of interest in berries. Food Hydrocolloids, 92(November 2018), 74-85. https://doi.org/10.1016/j.foodhyd.2019.01.039

12. Glencross, B. (2015). Understanding the nutritional and biological constraints of ingredients to optimize their application in aquaculture feeds. In Aquafeed Formulation (pp. 33-73). Elsevier Inc. https://doi.org/10.1016/B978-0-12-800873-7.00003-8

13. Gogna, N., Hamid, N., \& Dorai, K. (2015). Metabolomic profiling of the phytomedicinal constituents of Carica papaya L. leaves and seeds by $1 \mathrm{H}$ NMR spectroscopy and multivariate statistical analysis. 
Journal of Pharmaceutical and Biomedical Analysis, 115, 74-85.

https://doi.org/10.1016/j.jpba.2015.06.035

14. Golijan, J., Milinčić, D. D., Petronijević, R., Pešić, M. B., Barać, M. B., Sečanski, M., Lekić, S., \& Kostić, A. (2019). The fatty acid and triacylglycerol profiles of conventionally and organically produced grains of maize, spelt and buckwheat. Journal of Cereal Science, 90(June). https://doi.org/10.1016/j.jcs.2019.102845

15. Granato, D., Cardoso, C., Oliveira, D., Solange, M., Caruso, F., Araújo, L., Nagato, F., \& Alaburda, J. (2014). Feasibility of different chemometric techniques to differentiate commercial Brazilian sugarcane spirits based on chemical markers. FRIN, 60, 212-217. https://doi.org/10.1016/j.foodres.2013.09.044

16. Granato, D., de Araújo Calado, V. Ô. M., \& Jarvis, B. (2014). Observations on the use of statistical methods in Food Science and Technology. Food Research International, 55, 137-149. https://doi.org/10.1016/j.foodres.2013.10.024

17. Green, H. S., Li, X., De Pra, M., Lovejoy, K. S., Steiner, F., Acworth, I. N., \& Wang, S. C. (2020). A rapid method for the detection of extra virgin olive oil adulteration using UHPLC-CAD profiling of triacylglycerols and PCA. Food Control, 107(April 2019), 106773. https://doi.org/10.1016/j.foodcont.2019.106773

18. Hair, J. F., Black, W. C., Babin, B. J., \& Anderson, R. E. (2014). Multivariate data analysis. In Pearson Education Limited. https://doi.org/10.1007/978-3-319-01517-0_3

19. Idris, M. H. H., Manaf, Y. N., Desa, M. N. M., Hashim, A. M., Sani, M. S. A., Zaki, N. N. M., Yuswan, M. H., Kamaruddin, M. S., Hassan, M. S., Yusof, Y. A., \& Mustafa, S. (2021). A conjunction of sn-2 fatty acids and overall fatty acid composition combined with chemometric techniques increase the effectiveness of lard detection in fish feed. Chemometrics and Intelligent Laboratory Systems, 213(March), 104308. https://doi.org/10.1016/j.chemolab.2021.104308

20. Indelicato, S., Bongiorno, D., Pitonzo, R., Di Stefano, V., Calabrese, V., Indelicato, S., \& Avellone, G. (2017). Triacylglycerols in edible oils: Determination, characterization, quantitation, chemometric approach and evaluation of adulterations. Journal of Chromatography A, 1515, 1-16. https://doi.org/10.1016/j.chroma.2017.08.002

21. Indrasti, D., Che Man, Y. B., Mustafa, S., \& Hashim, D. M. (2010). Lard detection based on fatty acids profile using comprehensive gas chromatography hyphenated with time-of-flight mass spectrometry. Food Chemistry, 122(4), 1273-1277. https://doi.org/10.1016/j.foodchem.2010.03.082

22. Ismail, A. M., Sani, M. S. A., Azid, A., Zaki, N. N. M., Arshad, S., Tukiran, N. A., Abidin, S. A. S. Z., Samsudin, M. S., \& Ismail, A. (2021). Food forensics on gelatine source via ultra-high-performance liquid chromatography diode-array detector and principal component analysis. SN Applied Sciences, 3(79), 1-19. https://doi.org/10.1007/s42452-020-04061-7

23. Jasour, M. S., Wagner, L., Sundekilde, U. K., Larsen, B. K., Rasmussen, H. T., Hjermitslev, N. H., Hammershøj, M., Dalsgaard, A. J. T., \& Dalsgaard, T. K. (2018). Fishmeal with different levels of biogenic amines in aquafeed: Comparison of feed protein quality, fish growth performance, and 
metabolism. Aquaculture, 488(November 2017), 80-89.

https://doi.org/10.1016/j.aquaculture.2018.01.030

24. Juahir, H., Zain, S. M., Yusoff, M. K., Hanidza, T. I. T., Armi, a S. M., Toriman, M. E., \& Mokhtar, M. (2011). Spatial water quality assessment of Langat River Basin (Malaysia) using environmetric techniques. Environmental Monitoring and Assessment, 173(1-4), 625-641. https://doi.org/10.1007/s10661-010-1411-x

25. Kaiser, H. F. (1974). An index of factorial simplicity. Psychometrika, 39(1), 31-36.

26. Khallouki, F., Ricarte, I., Breuer, A., \& Owen, R. W. (2018). Characterization of phenolic compounds in mature Moroccan Medjool date palm fruits (Phoenix dactylifera) by HPLC-DAD-ESI-MS. Journal of Food Composition and Analysis, 70, 63-71. https://doi.org/10.1016/j.jfca.2018.03.005

27. Mercader, A. G., Duchowicz, P. R., \& Sivakumar, P.. (2016). Chemometrics applications and research: QSAR in medicinal chemistry. Apple Academic Press, Inc., 1-446.

28. Muflih, B. K., Ahmad, N. S., Jamaludin, M. A., \& Nordin, N. F. H. (2017). The concept and component of contaminated animals (al-jallalah animals). International Food Research Journal, 24(December), 436-440.

29. Mutalib, S. A., Muin, N. M., Abdullah, A., Hassan, O., Wan Mustapha, W. A., Abdullah Sani, N., \& Maskat, M. Y. (2015). Sensitivity of polymerase chain reaction (PCR)-southern hybridization and conventional PCR analysis for Halal authentication of gelatin capsules. LWT - Food Science and Technology, 63(1), 714-719. https://doi.org/10.1016/j.Iwt.2015.03.006

30. Naquiah, A. N. N., Marikkar, J. M.., Mirghani, M. E. ., Nurrulhidayah, A. F., \& Yanty, N. A. M. (2017). Differentiation of fractionated components of lard from other animal fats using different analytical techniques. Sains Malaysiana, 46(2), 209-216.

31. Noorzyanna, Y., Marikkar, N., Mustafa, S., \& Mat Sahri, M. (2017). Composition and thermal analysis of ternary mixtures of avocado fat:palm stearin:cocoa butter (Avo:PS:CB). International Journal of Food Properties, 20(2), 465-474. https://doi.org/10.1080/10942912.2016.1166130

32. Razali, N. M., Wah, Y. B., \& Sciences, M. (2011). Power comparisons of Shapiro-Wilk, KolmogorovSmirnov, Lilliefors and Anderson-Darling tests. Journal of Statistical Modeling and Analytics, 2(1), 21-33.

33. Rodriguez, A. (2020). Know your data: Evaluation of normality for continuous variables and tools to deal with non-normal distributions. Medicina Clínica, 154(4), 142-145.

https://doi.org/10.1016/j.medcle.2019.05.011

34. Romi Mukherjee, S. (2014). Global Halal: Meat, money, and religion. Religions, 5(1), 22-75. https://doi.org/10.3390/rel5010022

35. Saiful, M., Azid, A., Iskandar, S., Shirwan, M., Sani, A., \& Lananan, F. (2019). Comparison of prediction model using spatial discriminant analysis for marine water quality index in mangrove estuarine zones. Marine Pollution Bulletin, 141(February 2018), 472-481.

https://doi.org/10.1016/j.marpolbul.2019.02.045 
36. Sharin, S. N., Sani, M. S. A., Jaafar, M. A., Yuswan, M. H., Kassim, N. K., Manaf, Y. N., Wasoh, H., Zaki, N. N. M., \& Hashim, A. M. (2021). Discrimination of Malaysian stingless bee honey from different entomological origins based on physicochemical properties and volatile compound profiles using chemometrics and machine learning. Food Chemistry, 346(June 2020), 128654.

https://doi.org/10.1016/j.foodchem.2020.128654

37. Tyapkova, O., Osen, R., Wagenstaller, M., Baier, B., Specht, F., \& Zacherl, C. (2016). Replacing fishmeal with oilseed cakes in fish feed - A study on the influence of processing parameters on the extrusion behavior and quality properties of the feed pellets. Journal of Food Engineering, 191, 28-36. https://doi.org/10.1016/j.jfoodeng.2016.07.006

38. Williams, B., \& Brown, T. (2012). Exploratory factor analysis: A five-step guide for novices. Journal of Emergengy Primary Health Care, 8(3).

39. Yanty, N. A. M., Marikkar, J. M. N., \& Abdulkarim, S. M. (2014a). Determination of types of fat ingredient in some commercial biscuit formulations. International Food Research Journal, 21(1), $277-282$.

40. Yanty, N. A. M., Marikkar, J. M. N., \& Abdulkarim, S. M. (2014b). Determination of types of fat ingredient in some commercial biscuit formulations. International Food Research Journal, 21(1), 277-282.

41. Yanty, N. A. M., Marikkar, J. M. N., Man, Y. B. C., \& Long, K. (2011). Composition and thermal analysis of lard stearin and lard olein. Journal of Oleo Science, 338(7), 333-338.

42. Yanty, N. A. M., Marikkar, J. M. N., Miskandar, M. S., Bockstaele, F. Van, Dewettinck, K., \& Nusantoro, B. P. (2017). Compatibility of selected plant-based shortening as lard substitute: Microstructure, polymorphic forms and textural properties. Grasas $Y$ Aceites, 68(1), 1-8.

https://doi.org/10.3989/gya.0813162

43. Yap, B. K., \& Gam, L. H. (2019). Differentiation of bovine from porcine gelatin capsules using gel electrophoresis method. Food Chemistry, 274(August 2018), 16-19.

https://doi.org/10.1016/j.foodchem.2018.08.111

\section{Tables}

Table 1: The detected outliers and mean of triacylglycerols and thermal properties of fish feed

${ }^{1} \mathrm{LLLn}=$ dilinoleoyl-3-linolenileoyl glycerol, LLL = trilinoleoyl glycerol, $\mathrm{MMM}=$ trimyristoyl glycerol, OLL = leoyl-1-oleoyl glycerol, PLL = dilinoleoyl-1-palmitoyl

glycerol, MPL = myristoyl palmitoyl-linoleoyl glycerol, OOL = dioleoyl-3-linoleoyl glycerol, $\mathrm{POL}=$ palmitoyl-linoleoyl glycerol, PPL = dipalmitoyl-1-linoleoyl

glycerol, OOO = trioleoyl glycerol, $\mathrm{POO}=$ dioleoyl-1-palmitoyl glycerol, PPO = dipalmitoyl-3-oleoyl glycerol, PPP almitoyl glycerol, SOO = dioleoyl-1-stearoyl

glycerol, PSO = palmitoyl-stearoyl-oleoyl glycerol, PPS = dipalmitoyl-3-stearoyl glycerol, SSS = tristearoyl ol, SOS =1,3-distearoyl-2-oleoyl and SPO = 1-stearoyl-2-

palmitoyl-3-oleoylrac-glycerol.

${ }^{2} \mathrm{ICT}=$ initial cooling temperature, $\mathrm{CT}=$ cooling temperature, $\mathrm{FCT}=$ final cooling temperature, $\mathrm{IHT}=$ initial 


\begin{tabular}{|c|c|c|c|c|c|c|c|c|c|c|}
\hline \multirow[t]{2}{*}{$\begin{array}{l}\text { Variable, } \\
\text { (unit) }^{1,2}\end{array}$} & \multicolumn{2}{|c|}{$\begin{array}{l}\text { Fish feed with } \\
0: 100 \\
\text { lard-palm-oil } \\
\text { mixture }^{3}\end{array}$} & \multicolumn{2}{|c|}{$\begin{array}{l}\text { Fish feed with } \\
25: 75 \\
\text { lard-palm-oil } \\
\text { mixture }^{3}\end{array}$} & \multicolumn{2}{|c|}{$\begin{array}{l}\text { Fish feed with } \\
50: 50 \\
\text { lard-palm-oil } \\
\text { mixture }^{3}\end{array}$} & \multicolumn{2}{|c|}{$\begin{array}{l}\text { Fish feed with } \\
75: 25 \\
\text { lard-palm-oil } \\
\text { mixture }^{3}\end{array}$} & \multicolumn{2}{|c|}{$\begin{array}{l}\text { Fish feed with } \\
\text { 100:0 } \\
\text { lard-palm-oil } \\
\text { mixture }^{3}\end{array}$} \\
\hline & $\begin{array}{l}\text { Number } \\
\text { of } \\
\text { outliers }\end{array}$ & Mean & $\begin{array}{l}\text { Number } \\
\text { of } \\
\text { outliers }\end{array}$ & Mean & $\begin{array}{l}\text { Number } \\
\text { of } \\
\text { outliers }\end{array}$ & Mean & $\begin{array}{l}\text { Number } \\
\text { of } \\
\text { outliers }\end{array}$ & Mean & $\begin{array}{l}\text { Number } \\
\text { of } \\
\text { outliers }\end{array}$ & Mean \\
\hline \multicolumn{11}{|c|}{ Triacylglycerol (TAG) } \\
\hline $\begin{array}{l}\text { LLLn } \\
(\%)\end{array}$ & 0 & $\begin{array}{l}1.46 \pm \\
1.06^{\mathrm{a}}\end{array}$ & 0 & $\begin{array}{l}1.96 \pm \\
1.28^{\mathrm{a}}\end{array}$ & 0 & $\begin{array}{l}2.10 \pm \\
1.38^{\mathrm{a}}\end{array}$ & 0 & $\begin{array}{l}2.47 \pm \\
1.35^{\mathrm{a}}\end{array}$ & 0 & $\begin{array}{l}2.72 \pm \\
1.59^{\mathrm{a}}\end{array}$ \\
\hline LLL (\%) & 0 & $\begin{array}{l}0.29 \pm \\
0.14^{\mathrm{c}}\end{array}$ & 0 & $\begin{array}{l}0.52 \pm \\
0.22^{\mathrm{bc}}\end{array}$ & $\begin{array}{l}1 \text { (LP3- } \\
1)\end{array}$ & $\begin{array}{l}0.55 \pm \\
0.18^{\mathrm{bc}}\end{array}$ & 0 & $\begin{array}{l}0.70 \pm \\
0.38^{\mathrm{ab}}\end{array}$ & 0 & $\begin{array}{l}0.98 \pm \\
0.31^{\mathrm{a}}\end{array}$ \\
\hline OLL (\%) & 0 & $\begin{array}{l}2.09 \pm \\
1.00^{\mathrm{d}}\end{array}$ & 0 & $\begin{array}{l}3.21 \pm \\
1.03^{\mathrm{cd}}\end{array}$ & 0 & $\begin{array}{l}4.12 \pm \\
1.08^{\mathrm{bc}}\end{array}$ & 0 & $\begin{array}{l}4.98 \pm \\
0.98^{\mathrm{ab}}\end{array}$ & 0 & $\begin{array}{l}6.10 \pm \\
0.95^{\mathrm{a}}\end{array}$ \\
\hline PLL (\%) & 0 & $\begin{array}{l}4.31 \pm \\
0.70^{\mathrm{d}}\end{array}$ & 0 & $\begin{array}{l}5.57 \pm \\
0.59^{\mathrm{c}}\end{array}$ & $\begin{array}{l}1 \text { (LP3- } \\
6)\end{array}$ & $\begin{array}{l}6.25 \pm \\
0.68^{\mathrm{c}}\end{array}$ & 0 & $\begin{array}{l}7.33 \pm \\
0.65^{b}\end{array}$ & 1 (L5-1) & $\begin{array}{l}8.73 \pm \\
0.44^{\mathrm{a}}\end{array}$ \\
\hline MPL (\%) & 0 & $\begin{array}{l}0.55 \pm \\
0.25^{\mathrm{a}}\end{array}$ & 0 & $\begin{array}{l}0.47 \pm \\
0.28^{\mathrm{a}}\end{array}$ & 0 & $\begin{array}{l}0.55 \pm \\
1.54^{\mathrm{a}}\end{array}$ & 0 & $\begin{array}{l}0.03 \pm \\
0.04^{\mathrm{a}}\end{array}$ & 0 & $\begin{array}{l}0.32 \pm \\
0.31^{\mathrm{a}}\end{array}$ \\
\hline OOL (\%) & 0 & $\begin{array}{l}3.09 \pm \\
0.56^{\mathrm{e}}\end{array}$ & 0 & $\begin{array}{l}4.31 \pm \\
0.59^{\mathrm{d}}\end{array}$ & $\begin{array}{l}1 \text { (LP3- } \\
6)\end{array}$ & $\begin{array}{l}5.35 \pm \\
0.49^{\mathrm{c}}\end{array}$ & 0 & $\begin{array}{l}6.73 \pm \\
0.50^{\mathrm{b}}\end{array}$ & 0 & $\begin{array}{l}7.97 \pm \\
0.36^{\mathrm{a}}\end{array}$ \\
\hline POL (\%) & 0 & $\begin{array}{l}13.55 \\
\pm \\
0.34^{\mathrm{e}}\end{array}$ & 0 & $\begin{array}{l}15.77 \\
\pm 0.41^{d}\end{array}$ & 0 & $\begin{array}{l}17.88 \\
\pm 0.82^{\mathrm{C}}\end{array}$ & 0 & $\begin{array}{l}20.03 \\
\pm \\
0.64^{\mathrm{b}}\end{array}$ & 1 (L5-2) & $\begin{array}{l}22.32 \\
\pm 0.82^{\mathrm{a}}\end{array}$ \\
\hline PPL (\%) & 0 & $\begin{array}{l}11.20 \\
\pm \\
0.82^{\mathrm{a}}\end{array}$ & 0 & $\begin{array}{l}9.05 \pm \\
0.59^{b}\end{array}$ & 0 & $\begin{array}{l}7.12 \pm \\
0.53^{\mathrm{c}}\end{array}$ & 0 & $\begin{array}{l}4.92 \pm \\
0.31^{\mathrm{d}}\end{array}$ & 0 & $\begin{array}{l}2.61 \pm \\
0.19^{\mathrm{e}}\end{array}$ \\
\hline OOO (\%) & 0 & $\begin{array}{l}5.12 \pm \\
0.30^{\mathrm{a}}\end{array}$ & 0 & $\begin{array}{l}5.10 \pm \\
0.31^{\mathrm{a}}\end{array}$ & 0 & $\begin{array}{l}5.07 \pm \\
0.31^{\mathrm{a}}\end{array}$ & 0 & $\begin{array}{l}5.04 \pm \\
0.26^{\mathrm{a}}\end{array}$ & 0 & $\begin{array}{l}5.20 \pm \\
0.49^{\mathrm{a}}\end{array}$ \\
\hline POO (\%) & 0 & $\begin{array}{l}28.65 \\
\pm \\
1.56^{\mathrm{a}}\end{array}$ & 0 & $\begin{array}{l}26.44 \\
\pm 1.46^{b}\end{array}$ & 0 & $\begin{array}{l}25.01 \\
\pm 1.40^{\mathrm{b}}\end{array}$ & 0 & $\begin{array}{l}22.93 \\
\pm \\
1.17^{\mathrm{C}}\end{array}$ & 0 & $\begin{array}{l}20.93 \\
\pm \\
1.14^{\mathrm{d}}\end{array}$ \\
\hline PPO (\%) & 0 & $\begin{array}{l}22.52 \\
\pm \\
1.54^{\mathrm{a}}\end{array}$ & 0 & $\begin{array}{l}18.77 \\
\pm 1.61^{b}\end{array}$ & 0 & $\begin{array}{l}15.98 \\
\pm 1.16^{\mathrm{c}}\end{array}$ & 0 & $\begin{array}{l}12.37 \\
\pm \\
0.86^{\mathrm{d}}\end{array}$ & $\begin{array}{l}2 \text { (L5-1, } \\
\text { L5-7) }\end{array}$ & $\begin{array}{l}8.88 \pm \\
0.30^{\mathrm{e}}\end{array}$ \\
\hline PPP (\%) & 0 & $\begin{array}{l}0.00 \pm \\
0.00^{\mathrm{b}}\end{array}$ & 0 & $\begin{array}{l}0.00 \pm \\
0.00^{\mathrm{b}}\end{array}$ & 0 & $\begin{array}{l}0.00 \pm \\
0.00^{\mathrm{b}}\end{array}$ & $\begin{array}{l}2 \text { (LP4- } \\
2, \text { LP4- } \\
3 \text { ) }\end{array}$ & $\begin{array}{l}0.24 \pm \\
0.09^{\mathrm{a}}\end{array}$ & 0 & $\begin{array}{l}0.18 \pm \\
0.17^{\mathrm{a}}\end{array}$ \\
\hline SOO (\%) & 0 & $\begin{array}{l}1.30 \pm \\
1.41^{\mathrm{ab}}\end{array}$ & 0 & $\begin{array}{l}1.38 \pm \\
1.37^{\mathrm{ab}}\end{array}$ & $\begin{array}{l}1 \text { (LP3- } \\
4)\end{array}$ & $\begin{array}{l}0.50 \pm \\
0.48^{\mathrm{b}}\end{array}$ & 0 & $\begin{array}{l}1.39 \pm \\
1.72^{\mathrm{ab}}\end{array}$ & 0 & $\begin{array}{l}2.56 \pm \\
1.34^{\mathrm{a}}\end{array}$ \\
\hline SPO (\%) & 0 & $\begin{array}{l}2.40 \pm \\
1.95^{\mathrm{a}}\end{array}$ & 0 & $\begin{array}{l}1.89 \pm \\
2.83^{\mathrm{a}}\end{array}$ & 0 & $\begin{array}{l}0.00 \pm \\
0.00^{\mathrm{a}}\end{array}$ & 0 & $\begin{array}{l}2.30 \pm \\
3.45^{\mathrm{a}}\end{array}$ & 0 & $\begin{array}{l}0.00 \pm \\
0.00^{\mathrm{a}}\end{array}$ \\
\hline PPS (\%) & 0 & $\begin{array}{l}2.45 \pm \\
1.85^{\mathrm{b}}\end{array}$ & 0 & $\begin{array}{l}3.22 \pm \\
2.43^{\mathrm{ab}}\end{array}$ & $\begin{array}{l}1 \text { (LP3- } \\
4)\end{array}$ & $\begin{array}{l}6.36 \pm \\
0.69^{\mathrm{a}}\end{array}$ & 0 & $\begin{array}{l}2.71 \pm \\
3.92^{\mathrm{ab}}\end{array}$ & 0 & $\begin{array}{l}2.89 \pm \\
3.84^{\mathrm{ab}}\end{array}$ \\
\hline SOS (\%) & 0 & $\begin{array}{l}0.00 \pm \\
0.00^{\mathrm{b}}\end{array}$ & 0 & $\begin{array}{l}0.23 \pm \\
0.25^{\mathrm{ab}}\end{array}$ & 0 & $\begin{array}{l}0.12 \pm \\
0.20^{\mathrm{ab}}\end{array}$ & 0 & $\begin{array}{l}0.26 \pm \\
0.26^{\mathrm{ab}}\end{array}$ & 0 & $\begin{array}{l}0.33 \pm \\
0.30^{\mathrm{a}}\end{array}$ \\
\hline SSS (\%) & 0 & $\begin{array}{l}0.00 \pm \\
0.00^{\mathrm{b}}\end{array}$ & $\begin{array}{l}1 \text { (LP2- } \\
5)\end{array}$ & $\begin{array}{l}0.04 \pm \\
0.07^{\mathrm{ab}}\end{array}$ & 0 & $\begin{array}{l}0.00 \pm \\
0.00^{\mathrm{ab}}\end{array}$ & 0 & $\begin{array}{l}0.16 \pm \\
0.17^{\mathrm{a}}\end{array}$ & 0 & $\begin{array}{l}0.12 \pm \\
0.14^{\mathrm{ab}}\end{array}$ \\
\hline $\begin{array}{l}\text { MMM } \\
(\%)\end{array}$ & 0 & $\begin{array}{l}0.10 \pm \\
0.15^{\mathrm{a}}\end{array}$ & $\begin{array}{l}2 \text { (LP2- } \\
1, \text { LP2- }\end{array}$ & $\begin{array}{l}0.03 \pm \\
0.05^{\mathrm{a}}\end{array}$ & $\begin{array}{l}2 \text { (LP3- } \\
1, \text { LP3- }\end{array}$ & $\begin{array}{l}0.03 \pm \\
0.05^{\mathrm{a}}\end{array}$ & 0 & $\begin{array}{l}0.21 \pm \\
0.35^{\mathrm{a}}\end{array}$ & 1 (L5-1) & $\begin{array}{l}0.12 \pm \\
0.15^{\mathrm{a}}\end{array}$ \\
\hline
\end{tabular}


3) 3)

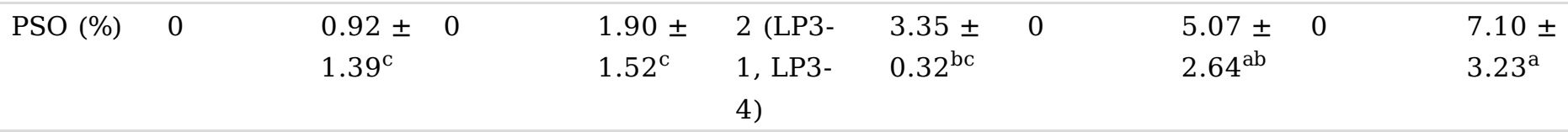

Thermal properties (TP) $\underline{2}$

\begin{tabular}{|c|c|c|c|c|c|c|c|c|c|c|}
\hline $\mathrm{CST}\left({ }^{\circ} \mathrm{C}\right)$ & 0 & $\begin{array}{l}4.68 \pm \\
0.47^{\mathrm{d}}\end{array}$ & 0 & $\begin{array}{l}8.37 \pm \\
1.46^{\mathrm{c}}\end{array}$ & 0 & $\begin{array}{l}10.34 \\
\pm 0.45^{\mathrm{b}}\end{array}$ & 0 & $\begin{array}{l}12.51 \\
\pm \\
0.62^{\mathrm{a}}\end{array}$ & 0 & $\begin{array}{l}13.53 \\
\pm 0.65^{\mathrm{a}}\end{array}$ \\
\hline $\begin{array}{l}\text { CPT1 } \\
\left({ }^{\circ} \mathrm{C}\right)\end{array}$ & 0 & nd & 0 & $\begin{array}{l}2.23 \pm \\
3.35^{\mathrm{c}}\end{array}$ & 0 & $\begin{array}{l}8.21 \pm \\
0.92^{\mathrm{b}}\end{array}$ & 0 & $\begin{array}{l}10.24 \\
\pm \\
1.08^{\mathrm{ab}}\end{array}$ & 0 & $\begin{array}{l}11.16 \\
\pm 1.49^{\mathrm{a}}\end{array}$ \\
\hline $\begin{array}{l}\text { CPT2 } \\
\left({ }^{\circ} \mathrm{C}\right)\end{array}$ & 0 & nd & 0 & $\begin{array}{l}4.19 \pm \\
1.26^{\mathrm{a}}\end{array}$ & 0 & $\begin{array}{l}4.57 \pm \\
1.08^{\mathrm{a}}\end{array}$ & 0 & $\begin{array}{l}4.87 \pm \\
1.31^{\mathrm{a}}\end{array}$ & 0 & $\begin{array}{l}5.51 \pm \\
1.43^{\mathrm{a}}\end{array}$ \\
\hline $\begin{array}{l}\text { CPT3 } \\
\left({ }^{\circ} \mathrm{C}\right)\end{array}$ & 0 & $\begin{array}{l}0.45 \pm \\
0.60^{\mathrm{d}}\end{array}$ & 0 & $\begin{array}{l}1.28 \pm \\
0.52^{\mathrm{cd}}\end{array}$ & 0 & $\begin{array}{l}2.18 \pm \\
0.84^{\mathrm{bc}}\end{array}$ & 0 & $\begin{array}{l}2.70 \pm \\
1.06^{\mathrm{ab}}\end{array}$ & 0 & $\begin{array}{l}3.73 \pm \\
1.68^{\mathrm{a}}\end{array}$ \\
\hline $\begin{array}{l}\text { CPT4 } \\
\left({ }^{\circ} \mathrm{C}\right)\end{array}$ & 0 & $\begin{array}{l}-3.43 \\
\pm \\
0.42^{\mathrm{a}}\end{array}$ & 0 & $\begin{array}{l}-2.95 \pm \\
1.01^{\mathrm{a}}\end{array}$ & $\begin{array}{l}1 \text { (LP3- } \\
1)\end{array}$ & $\begin{array}{l}-7.67 \pm \\
16.22^{\mathrm{a}}\end{array}$ & 0 & $\begin{array}{l}-1.69 \\
\pm \\
2.20^{\mathrm{a}}\end{array}$ & 0 & $\begin{array}{l}-1.81 \pm \\
2.17^{\mathrm{a}}\end{array}$ \\
\hline $\begin{array}{l}\text { CPT5 } \\
\left({ }^{\circ} \mathrm{C}\right)\end{array}$ & 0 & $\begin{array}{l}-19.28 \\
\pm \\
0.71^{\mathrm{a}}\end{array}$ & 0 & $\begin{array}{l}-18.61 \\
\pm 0.96^{\mathrm{a}}\end{array}$ & 0 & $\begin{array}{l}-16.82 \\
\pm 1.29^{a}\end{array}$ & 0 & $\begin{array}{l}-14.79 \\
\pm \\
0.62^{\mathrm{a}}\end{array}$ & 0 & $\begin{array}{l}-18.63 \\
\pm \\
17.09^{a}\end{array}$ \\
\hline $\begin{array}{l}\text { CPT6 } \\
\left({ }^{\circ} \mathrm{C}\right)\end{array}$ & 0 & nd & 0 & $\begin{array}{l}-13.69 \\
\pm \\
20.53^{\mathrm{ab}}\end{array}$ & 0 & $\begin{array}{l}-26.00 \\
\pm \\
19.79^{b c}\end{array}$ & 0 & $\begin{array}{l}-43.37 \\
\pm \\
8.01^{\mathrm{c}}\end{array}$ & 0 & $\begin{array}{l}-39.28 \\
\pm \\
12.05^{c}\end{array}$ \\
\hline $\mathrm{CET}\left({ }^{\circ} \mathrm{C}\right)$ & 0 & $\begin{array}{l}-29.92 \\
\pm \\
5.51^{\mathrm{a}}\end{array}$ & 0 & $\begin{array}{l}-39.51 \\
\pm 8.57^{b}\end{array}$ & 0 & $\begin{array}{l}-46.66 \\
\pm \\
4.97^{\mathrm{bc}}\end{array}$ & 0 & $\begin{array}{l}-51.54 \\
\pm \\
5.24^{\mathrm{c}}\end{array}$ & 0 & $\begin{array}{l}-49.13 \\
\pm 7.55^{\mathrm{c}}\end{array}$ \\
\hline $\operatorname{HST}\left({ }^{\circ} \mathrm{C}\right)$ & 0 & $\begin{array}{l}-28.15 \\
\pm \\
4.52^{\mathrm{a}}\end{array}$ & 0 & $\begin{array}{l}-26.37 \\
\pm 4.03^{\mathrm{a}}\end{array}$ & 0 & $\begin{array}{l}-25.67 \\
\pm 3.01^{\mathrm{a}}\end{array}$ & 0 & $\begin{array}{l}-27.06 \\
\pm \\
4.52^{\mathrm{a}}\end{array}$ & 0 & $\begin{array}{l}-33.46 \\
\pm \\
1.25^{b}\end{array}$ \\
\hline $\begin{array}{l}\text { HPT1 } \\
\left({ }^{\circ} \mathrm{C}\right)\end{array}$ & $1(\mathrm{P} 1-8)$ & $\begin{array}{l}-21.37 \\
\pm \\
3.76^{\mathrm{b}}\end{array}$ & 0 & $\begin{array}{l}-20.31 \\
\pm 3.24^{b}\end{array}$ & 0 & $\begin{array}{l}-18.82 \\
\pm \\
3.81^{\mathrm{ab}}\end{array}$ & 0 & $\begin{array}{l}-18.92 \\
\pm \\
1.40^{\mathrm{ab}}\end{array}$ & 0 & $\begin{array}{l}-13.01 \\
\pm 9.77^{a}\end{array}$ \\
\hline $\begin{array}{l}\text { HPT2 } \\
\left({ }^{\circ} \mathrm{C}\right)\end{array}$ & 0 & $\begin{array}{l}-6.49 \\
\pm \\
7.95^{\mathrm{a}}\end{array}$ & 0 & $\begin{array}{l}-5.83 \pm \\
7.83^{\mathrm{a}}\end{array}$ & 0 & $\begin{array}{l}-4.68 \pm \\
6.94^{\mathrm{a}}\end{array}$ & 0 & $\begin{array}{l}-3.86 \\
\pm \\
5.79^{a}\end{array}$ & 0 & $\begin{array}{l}-4.83 \pm \\
7.25^{\mathrm{a}}\end{array}$ \\
\hline $\begin{array}{l}\text { HPT3 } \\
\left({ }^{\circ} \mathrm{C}\right)\end{array}$ & 0 & $\begin{array}{l}0.40 \pm \\
2.01^{\mathrm{a}}\end{array}$ & 0 & $\begin{array}{l}0.60 \pm \\
1.29^{\mathrm{a}}\end{array}$ & 0 & $\begin{array}{l}1.84 \pm \\
2.77^{\mathrm{a}}\end{array}$ & 0 & $\begin{array}{l}0.70 \pm \\
1.04^{\mathrm{a}}\end{array}$ & 0 & $\begin{array}{l}0.00 \pm \\
0.00^{\mathrm{a}}\end{array}$ \\
\hline $\begin{array}{l}\text { HPT4 } \\
\left({ }^{\circ} \mathrm{C}\right)\end{array}$ & 0 & $\begin{array}{l}3.97 \pm \\
2.58^{\mathrm{a}}\end{array}$ & 0 & $\begin{array}{l}4.40 \pm \\
2.91^{\mathrm{a}}\end{array}$ & 0 & $\begin{array}{l}5.38 \pm \\
2.90^{\mathrm{a}}\end{array}$ & 0 & $\begin{array}{l}2.61 \pm \\
2.55^{\mathrm{a}}\end{array}$ & 0 & $\begin{array}{l}-2.76 \pm \\
0.89^{b}\end{array}$ \\
\hline $\begin{array}{l}\text { HPT5 } \\
\left({ }^{\circ} \mathrm{C}\right)\end{array}$ & 0 & nd & 0 & $\begin{array}{l}4.07 \pm \\
6.10^{\mathrm{b}}\end{array}$ & 0 & $\begin{array}{l}11.63 \\
\pm 8.87^{\mathrm{a}}\end{array}$ & 0 & $\begin{array}{l}15.44 \\
\pm \\
1.09^{a}\end{array}$ & 0 & $\begin{array}{l}16.74 \\
\pm 0.54^{\mathrm{a}}\end{array}$ \\
\hline $\begin{array}{l}\text { HPT6 } \\
\left({ }^{\circ} \mathrm{C}\right)\end{array}$ & 0 & nd & 0 & $\begin{array}{l}5.77 \pm \\
8.66^{\mathrm{b}}\end{array}$ & 0 & $\begin{array}{l}19.99 \\
\pm 2.27^{\mathrm{a}}\end{array}$ & 0 & $\begin{array}{l}21.22 \\
\pm \\
1.52^{\mathrm{a}}\end{array}$ & 0 & $\begin{array}{l}23.14 \\
\pm 1.71^{\mathrm{a}}\end{array}$ \\
\hline $\operatorname{HET}\left({ }^{\circ} \mathrm{C}\right)$ & 0 & $\begin{array}{l}15.26 \\
\pm \\
0.14^{\mathrm{d}}\end{array}$ & 0 & $\begin{array}{l}19.19 \\
\pm 2.28^{\mathrm{c}}\end{array}$ & 0 & $\begin{array}{l}22.55 \\
\pm 4.28^{b}\end{array}$ & 0 & $\begin{array}{l}27.29 \\
\pm \\
1.20^{\mathrm{a}}\end{array}$ & 0 & $\begin{array}{l}29.18 \\
\pm 1.85^{\mathrm{a}}\end{array}$ \\
\hline
\end{tabular}


Ig temperature, $\mathrm{HT}=$ heating temperature and $\mathrm{FHT}=$ final

heating temperature.

${ }^{3}$ Means with different superscript letter are significantly different $(p<0.05)$.

Table 2: Factor loading of triacylglycerols and thermal properties of fish feed 


\begin{tabular}{|c|c|c|c|c|}
\hline \multirow[t]{2}{*}{ Variable $^{1,2}$} & \multicolumn{2}{|c|}{$\begin{array}{l}\text { Factor loading (FL) of first } \\
\mathrm{PCA}^{3,4}\end{array}$} & \multicolumn{2}{|c|}{$\begin{array}{l}\text { Factor loading (FL) of second } \\
\text { PCA }^{3,4,5}\end{array}$} \\
\hline & PC1 & PC2 & PC1 & $\mathrm{PC2}$ \\
\hline \multicolumn{5}{|l|}{ Triacylglycerol (TAG) 1} \\
\hline LLLn & $-0.3693^{c}$ & $-0.8583^{\mathrm{a}}$ & $-0.4737^{c}$ & $-0.8067^{\mathrm{a}}$ \\
\hline LLL & $-0.6832^{\mathrm{b}}$ & $-0.4222^{\mathrm{C}}$ & $\mathrm{nt}$ & $\mathrm{nt}$ \\
\hline OLL & $-0.8417^{a}$ & $-0.5081^{\mathrm{b}}$ & $-0.9095^{\mathrm{a}}$ & $-0.3906^{c}$ \\
\hline PLL & $-0.9392^{\mathrm{a}}$ & $-0.2783^{c}$ & $-0.9768^{\mathrm{a}}$ & $-0.1464^{\mathrm{c}}$ \\
\hline MPL & $0.1756^{\mathrm{c}}$ & $0.1404^{\mathrm{C}}$ & nt & nt \\
\hline OOL & $-0.9676^{\mathrm{a}}$ & $-0.2034^{\mathrm{c}}$ & $-0.9912^{\mathrm{a}}$ & $-0.0718^{\mathrm{c}}$ \\
\hline POL & $-0.9554^{\mathrm{a}}$ & $0.1289^{c}$ & $-0.9431^{\mathrm{a}}$ & $0.2615^{\mathrm{c}}$ \\
\hline PPL & $0.9850^{\mathrm{a}}$ & $0.0934^{\mathrm{c}}$ & $0.9959^{\mathrm{a}}$ & $-0.0395^{c}$ \\
\hline $\mathrm{OOO}$ & $-0.0839^{c}$ & $-0.7550^{\mathrm{a}}$ & $-0.1840^{\mathrm{c}}$ & $-0.7549^{\mathrm{a}}$ \\
\hline $\mathrm{POO}$ & $0.9189^{\mathrm{a}}$ & $0.3358^{c}$ & $0.9608^{\mathrm{a}}$ & $0.2135^{c}$ \\
\hline PPO & $0.9786^{\mathrm{a}}$ & $0.1462^{\mathrm{c}}$ & $0.9964^{\mathrm{a}}$ & $0.0155^{\mathrm{c}}$ \\
\hline PPP & $-0.7287^{b}$ & $0.2232^{\mathrm{C}}$ & nt & $\mathrm{nt}$ \\
\hline SOO & $-0.2593^{c}$ & $0.5575^{\mathrm{b}}$ & nt & nt \\
\hline SPO & $0.2491^{\mathrm{c}}$ & $-0.0246^{\mathrm{C}}$ & nt & nt \\
\hline PPS & $0.0373^{\mathrm{C}}$ & $-0.4104^{\mathrm{c}}$ & nt & nt \\
\hline sos & $-0.3788^{c}$ & $0.6312^{\mathrm{b}}$ & nt & $\mathrm{nt}$ \\
\hline SSS & $-0.4686^{c}$ & $0.4293^{\mathrm{c}}$ & nt & $\mathrm{nt}$ \\
\hline MMM & $-0.2644^{\mathrm{C}}$ & $-0.4596^{\mathrm{c}}$ & nt & nt \\
\hline PSO & $-0.7682^{a}$ & $0.3448^{\mathrm{c}}$ & $-0.7236^{b}$ & $0.4748^{\mathrm{c}}$ \\
\hline \multicolumn{5}{|l|}{ Thermal property_(TP) $\underline{2}$} \\
\hline ICT & $-0.9202^{\mathrm{a}}$ & $0.0646^{\mathrm{c}}$ & $-0.9359^{\mathrm{a}}$ & $0.1833^{c}$ \\
\hline CT1 & $-0.6640^{\mathrm{b}}$ & $0.1120^{c}$ & nt & nt \\
\hline CT2 & $-0.2699^{c}$ & $0.8698^{\mathrm{a}}$ & $-0.1259^{c}$ & $0.9198^{\mathrm{a}}$ \\
\hline CT3 & $-0.7371^{b}$ & $0.6247^{b}$ & nt & nt \\
\hline CT4 & $-0.1084^{c}$ & $0.3735^{\mathrm{c}}$ & nt & nt \\
\hline CT5 & $-0.1564^{c}$ & $0.5707^{b}$ & nt & nt \\
\hline CT6 & $0.3836^{\mathrm{c}}$ & $-0.1570^{c}$ & nt & $\mathrm{nt}$ \\
\hline FCT & $0.6722^{\mathrm{b}}$ & $0.1775^{\mathrm{c}}$ & nt & $\mathrm{nt}$ \\
\hline IHT & $0.4695^{\mathrm{c}}$ & $0.6305^{\mathrm{b}}$ & nt & $\mathrm{nt}$ \\
\hline HT1 & $-0.4618^{c}$ & $0.6203^{b}$ & nt & nt \\
\hline HT2 & $-0.1364^{\mathrm{c}}$ & $-0.1235^{c}$ & nt & nt \\
\hline HT3 & $0.1405^{\mathrm{C}}$ & $0.5329^{b}$ & nt & nt \\
\hline HT4 & $0.6772^{\mathrm{b}}$ & $0.5265^{\mathrm{b}}$ & nt & nt \\
\hline HT5 & $-0.4831^{\mathrm{c}}$ & $0.4503^{\mathrm{c}}$ & nt & nt \\
\hline HT6 & $-0.5425^{\mathrm{b}}$ & $0.2279^{c}$ & nt & nt \\
\hline FHT & $-0.8845^{\mathrm{a}}$ & $0.3438^{\mathrm{c}}$ & $-0.8404^{\mathrm{a}}$ & $0.4689^{c}$ \\
\hline Eigenvalue & 13.3176 & 6.9003 & 8.9409 & 2.8404 \\
\hline Variability (\%) & 38.0503 & 19.7152 & 68.7759 & 21.8493 \\
\hline $\begin{array}{l}\text { Cumulative explained variability } \\
\text { (\%) }\end{array}$ & 38.0503 & 57.7655 & 68.7759 & 90.6252 \\
\hline Kaiser-Meyer-Olkin value & 0.5127 & & 0.8109 & \\
\hline
\end{tabular}


Note: ${ }^{1}$ LLLn = dilinoleoyl-3-linolenileoyl glycerol, LLL = trilinoleoyl glycerol, MMM = trimyristoyl glycerol, OLL = dilinoleoyl-1-oleoyl glycerol, PLL = dilinoleoyl-1-palmitoyl glycerol, MPL = myristoyl palmitoyl-linoleoyl glycerol, OOL = dioleoyl-3-linoleoyl glycerol, POL = palmitoyl-oleoyl-linoleoyl glycerol, PPL = dipalmitoyl-1-linoleoyl glycerol, $\mathrm{OOO}=$ trioleoyl glycerol, $\mathrm{POO}=$ dioleoyl-1-palmitoyl glycerol, PPO = dipalmitoyl-3-oleoyl glycerol, PPP = tripalmitoyl glycerol, SOO = dioleoyl-1-stearoyl glycerol, PSO = palmitoyl-stearoyl-oleoyl glycerol, PPS = dipalmitoyl-3-stearoyl glycerol,

SSS $=$ tristearoyl glycerol, SOS $=1$,3-distearoyl-2-oleoyl and SPO = 1-stearoyl-2-palmitoyl-3-oleoylracglycerol.

${ }^{2}$ ICT = initial cooling temperature, $\mathrm{CT}=$ cooling temperature, FCT = final cooling temperature, $\mathrm{IHT}=$ initial heating temperature, $\mathrm{HT}=$ heating temperature and $\mathrm{FHT}=$ final heating temperature.

${ }^{3 \mathrm{a}_{\mathrm{FL}} \geq|0.750|}=$ strong factor loading, ${ }^{\mathrm{b}}|0.500|<\mathrm{FL}<|0.749|=$ moderate factor loading and $\mathrm{C}_{\mathrm{FL}} \leq|0.499|=$ weak factor loading in the principal component

${ }^{4}$ Bold factor loading indicated strong factor loading in the principal component. ${ }^{5} \mathrm{nt}=$ the TAGs and TPs were not tested in the second PCA.

Tables 3 and 4 are in the supplementary files section.

\section{Figures}

(a) Triacylglycerol and thermal property plot (axes F1 and F2: $90.63 \%$ )

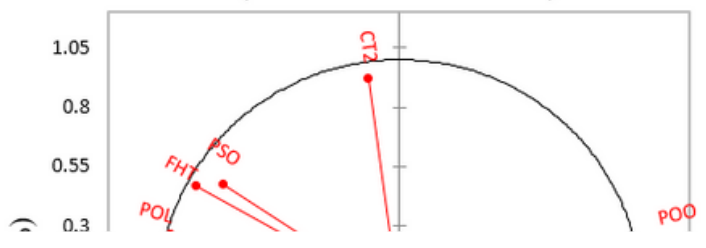

(b) Biplot of triacylglycerol and thermal property in fish feed (axes F1 and F2: $90.63 \%$ )

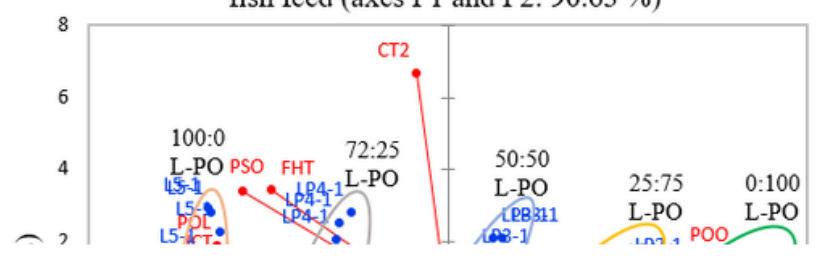

\section{Figure 1}

(a) Triacylglycerol and thermal properties plot and (b) biplot of triacylglycerol, thermal property, and fish feed 
Plot of training and testing datasets of fish feed (axes F1 and F2: $100.00 \%$ )

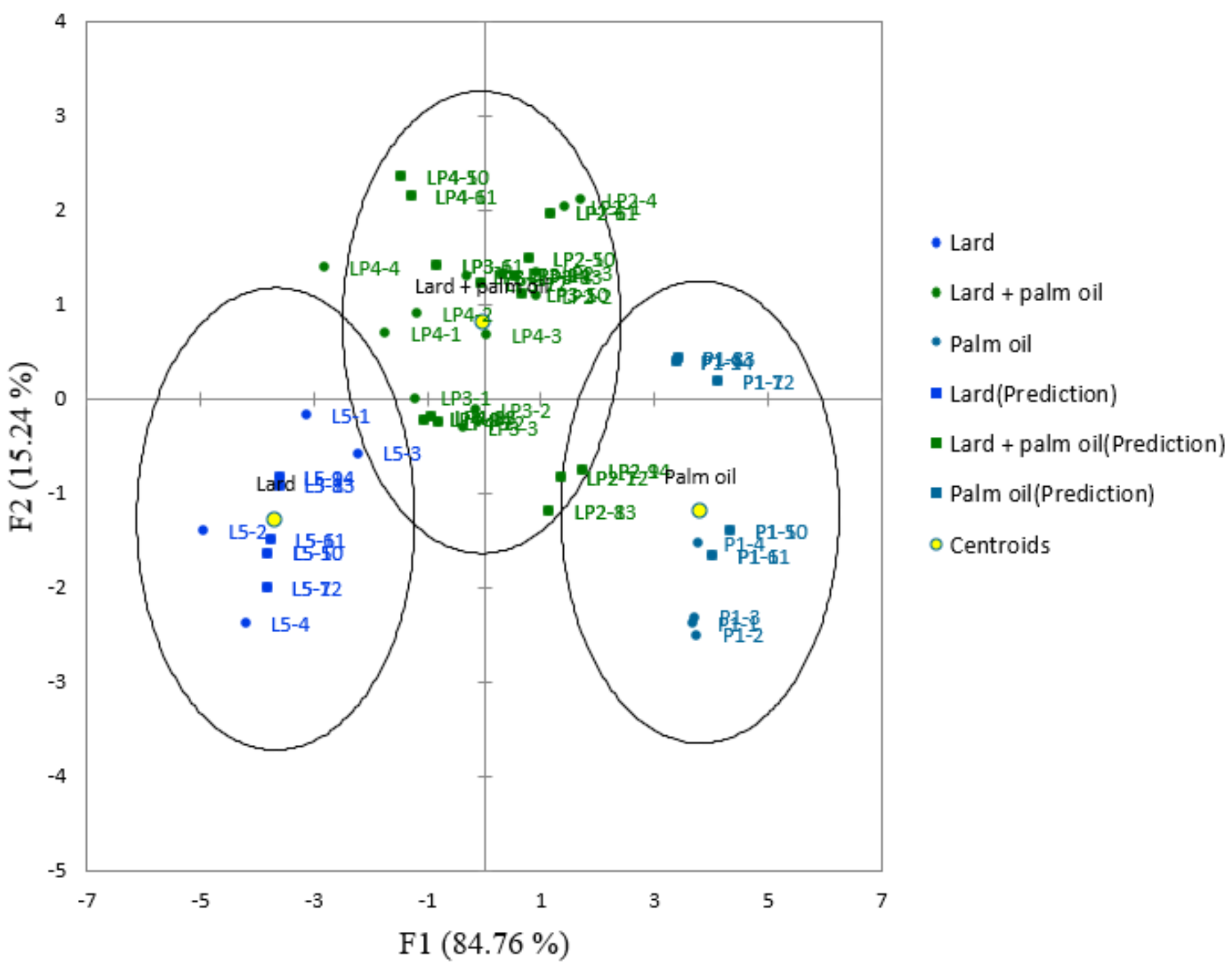

Figure 2

Plot of training and testing datasets of fish feed by discriminant analysis

\section{Supplementary Files}

This is a list of supplementary files associated with this preprint. Click to download.

- image.png

- image.png 